\title{
Improvement of Student Learning Outcomes with Blended-Learning Method (Offline and Virtual) on Momentum and Impulse Materials at SMAN 1 Sungai Tarab
}

\author{
Putri Angela $^{1 *}$, Marjoni Imamora Ali Umar ${ }^{2}$ \\ ${ }^{1}$ Physics Teacher, SMAN 1 Sungai Tarab, Batusangkar 27213, West Sumatra, Indonesia \\ ${ }^{2}$ Department of Physics Education, Faculty of Tarbiyah and Teacher Training, State Islamic \\ Institute (IAIN) Batusangkar, Batusangkar 27213, West Sumatra, Indonesia. \\ Tel: 0752-71150 Fax: 0752-71879 \\ *Email:putriangela2911@gmail.com
}

\section{Article History}

Received: 12 June 2021

Revised: 25 June 2021

Accepted: 29 June 2021

Published: 30 June 2021

\section{Key Words}

Blended learning; Learning outcomes;

Google classroom.

\begin{abstract}
The purpose of this study was to improve the student learning outcomes on momentum and impulse material in class X MIPA3 SMA Negeri 1 Sungai Tarab through the application of the blended learning method with face-to-face learning approaches and virtual by using google classroom application. The type of this research is Classroom Action Research (PTK) which is conducted in 2 cycles. The subjects of this study were students of class $\mathrm{X}$ MIPA3 SMA Negeri 1 Sungai Tarab, which consisted of 29 students (15 male and 14 female students). The research stages were planning, acting, observing, and reflecting. Data collection methods used were observation and tests. The data analysis technique uses such as observation sheets, descriptive statistics, namely: average score and percentage, standard deviation, minimum and maximum values. The results showed an increase in student learning outcomes of class X MIPA3 on momentum and impulse subjects. We can see this through the following indicators: 1) the percentage of student learning outcomes increases each cycle, from pre-cycle (17.24\%) to $(48.28 \%)$ and to (75.86\%) in cycle II; 2$)$ there is an increase in the average value of each cycle, namely in the pre-cycle (52.07) to (63.79) in the first cycle and (78.28) in the second cycle. The conclusion of this study is the application of the blended learning method with face-to-face learning approaches and google classroom can improve student learning outcomes.
\end{abstract}

\section{INTRODUCTION}

Physics is the primary subject that is always given to students at the SMA, SMK and MA level (Fitriani et al., 2014). In physics lessons, it guided students to see the relationship between theories of physics with everyday life (Kuspriyanto \& Siagian, 2013). Besides that, physics teaches about the origin of a concept that is carried out through experiments or practicums. This distinguishes it from other subjects, so that students who know the physics as knowledge of the origin of the concept in question. Covid-19 has hit all parts of the world, including Indonesia. The speed of the spread of this epidemic is quite fast and 
threatens all aspects of life, especially the economy and national resilience.

Besides that, the education sector is also part of the affected area which is quite worrying because it has implications for the progress of a nation (Ngalim, 2011). As an anticipatory measure, Indonesia has made a policy, especially for schools that may learn face-toface, or virtual/online. In addition, activities or events that have the potential to gather enormous crowds are also restricted. In other words, in order to break the chain of the spread of the Covid-19 outbreak quickly, social distancing is needed (Juliani, 2020).

This is reinforced by issuing a circular letter from the Ministry of Education and Culture which instructs to organize Teaching and Learning process (PBM) with the distance learning method (PJJ). Through this method, it gives the impression to students to learn from their homes through online learning. It also required teacher to innovate in the learning process. The PJJ method can take advantage of WhatsApp, Google Classroom, Moodle and others (Mamluah \& Maulidi, 2021).

PJJ learning by utilizing Information and Communication Technology (ICT), is a suitable method for all levels of education (elementary, junior high, high school and higher education). With ICT, teacher or lecturers can create an active, creative, effective and fun learning environment. In addition, ICT media can also increase motivation and make it easier for students to understand the material studied. Education in Indonesia is still relatively low and has not optimally succeeded, especially in learning physics (Supardi et al., 2015).

We found several problems in distance learning, in class X MIPA3 SMA Negeri 1 Sungai Tarab. The duration of face-to-face learning caused these problems at school only lasts half a day, namely from 07.30 to 11.45 WIB with 1 lesson for 30 minutes. This causes the time for learning physics quite less, and is believed to influence the achievement of student competencies. The difficulty of them evidences the lowest understanding and interest of students in receiving physics lessons answering the questions given. Some of them hesitated in giving an answer to a statement. Because of the lack of courage to express opinions and ask questions. When the material was delivered through the WhatsApp group, they saw that only a few students were active, either asking or responding to the questions given. They do not record again the material given because they only download it. Students consider physics lessons to be difficult and not fun to learn. The average result of the pre-test was only 52.07 where out of 29 students in class X MIPA3 who completed only 5 people, while 24 others were still below the Minimum Completeness Criteria (KKM). From these data, we can see that the achievement of physics learning outcomes for students in class $\mathrm{X}$ MIPA3 is still relatively low. Students consider physics as a difficult and unpleasant subject to learn.

We expect the results to provide an increase in students' physics learning outcomes. We intend it achieve perfectly the Basic Competence of learning. Failure to understand physics material causes students to be incomplete in learning, so they will have difficulty working on end-of-semester exams. Even though the requirements for grade promotion, they must be complete in studying physics. The daily test questions only contain certain basic competencies, while the end-ofsemester tests for grade promotion contain various basic competencies. This last test shows the result of student in one semester in physics subjects (Kayatun \& Kresnady, 2014).

Learning outcomes come from two words, namely "results" and "learning". The result is a product, which is an acquisition because of an activity or process that results in a functional change in input (Ngalim, 2011). Learning is a stage of change in all individual behavior that is relatively permanent because of experience and interaction with the environment that involves cognitive processes (Syah, 2004). According to Gagne and Briggs in (Sam's, 2010) learning outcomes are abilities that are obtained by someone after following the learning process.

For Teacher, learning outcomes are useful in summarizing their success and quality in teaching. Based on the results of learning, physics subjects obtained by students is still relatively low. For this reason, it is necessary to use learning methods that can improve student learning outcomes. One method that is in accordance with the millennial spirit of students is using learning media using the latest technology. Learning in the network (online) is 
a learning method that is required in the atmosphere during covid-19 pandemic. By using of good learning media that is suitable for online learning via cellphones (Darmawan, 2014) is highly recommended.

The results of Gheytasi et al. in (Darmawan, 2014) shows that students who interact a lot with applications on mobile phones are easier to understand the contents of reading texts. The development of ICT is used as a solution for the education. The learning method shifted from the classical method of lectures in class. Various other information and communication technology-based learning methods emerged, such as e-learning, smart classroom technology, virtual classrooms, blended learning and others. This is because of the COVID-19 pandemic. From the various learning methods above, researchers are interested in taking the Blended Learning method.

Blended learning which unifies a variety of learning methods that can be achieved by combining virtual and physical resources (Driscoll \& Carliner, 2005). In this study, it is reported the use of a combination of face-toface and virtual learning strategies using google classroom. This combination of face-to-face learning with classroom allows teacher to meet students in one room to learn with a synchronous (direct) communication model (Bonk \& Graham, 2012). This is believed to trigger active interaction between students, and students and teacher. The face-to-face teaching and learning process is carried out with due regard to strict health protocols. Meanwhile, virtual learning is carried out from their homes using the Google Classroom application as a media.

The results showed that this blended learning method was effective in increasing the class average score and the percentage of siring completeness, with the addition of treatment cycles given to students. The results of the class average value increased quite high compared to before the treatment, namely from 52.07 to 78.28 in the second cycle. An increase in student completeness, which is quite high, which is $75.86 \%$. from the previous result of $17.24 \%$ also accompanied this result.

\section{METHOD}

This research was called classroom action research (CAR) whose primary focus is to improve student learning outcomes using certain treatments (Sam's, 2010). The learning method used is blended learning (face to face and google classroom) on momentum and impulse material. This CAR consists of 4 stages such as planning, implementation, observation and reflection (see Figure 1). Problems encountered during the learning process (reflection), become a reference for improving observation planning, as well as re-reflecting in the next cycle until the problem is resolved (Aqib \& Diniati, 2009)(Sam's, 2010).

Students of class X MIPA3 SMA Negeri 1 Sungai Tarab, Tanah Datar Regency, West Sumatra Province are the research subjects in the study ( 29 students, namely 15 male students and 14 female students. We can see the distribution of the blended learning schedule in Table 1 . We carried this research out in physics subjects in the even semester of the 2020/2021 academic year on the material of momentum and impulse and their physical meaning in everyday life. The time of this research was in the Even Semester of the 2020/2021 Academic Year, starting on February 8-1 March 2021 (see Table 1)

Table 1. Schedule of Shift Changes for Students of Class X MIPA 3

\begin{tabular}{ccc}
\hline Date & Face to Face & Google Classroom \\
\hline 08 February 2021 & Shift 1 & Shift 2 \\
15 February 2021 & Shift 2 & Shift 1 \\
22 February 2021 & Shift 1 & Shift 2 \\
01 March 2021 & Shift 2 & Shift 1 \\
\hline
\end{tabular}




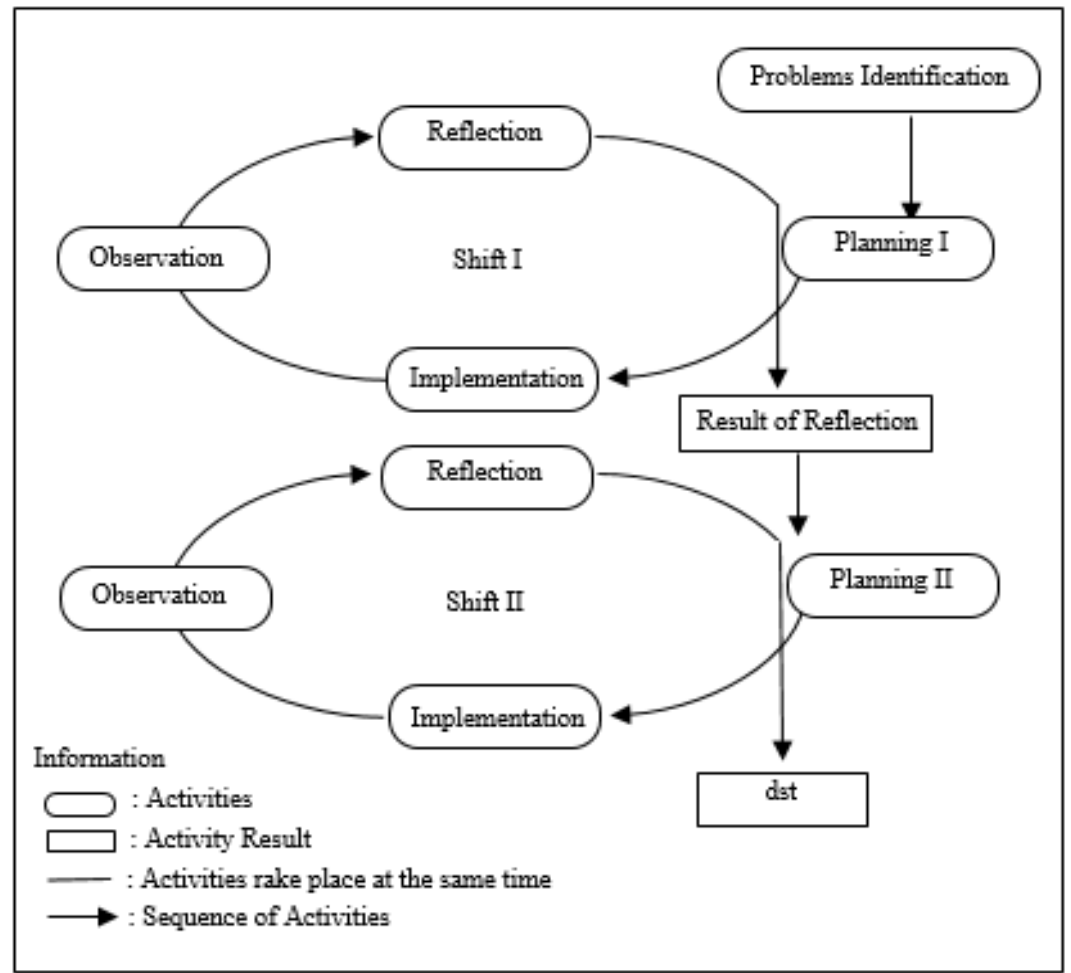

Figure 1. Stages of Classroom Action Research.

The data collection technique used is observation for data collection on student activities and tests for data collection on student learning outcomes. We intend observations for. The observation technique used is participatory observation, where the researcher is involved with the activities of the research subject (Sugiyono, 2011). The assessment format used is a Checklist as a list of observations, where the observer only needs to give a checklist mark on the presence or absence of the observed aspects in accordance with the observation guide that has been provided.

The type of test in this study is a learning outcome test to measure students' knowledge of the cognitive aspects of momentum and impulse material. In this study, the instrument used was a written test which was stated as multiple-choice questions 10 questions for the first cycle with a true score of 10 and a false value of 0 . In the second cycle consisted of 20 questions with a true score of 5 and a false value of 0 . Cycle I and Cycle II test scores were used to measure learning outcomes from the cognitive aspect, using quantitative analysis of the items with the formula:
Information:

$$
\mathrm{KB}=\mathrm{x} 100 \% \frac{T}{T t}
$$

$\mathrm{KB}=$ complete learning

$\mathrm{T}=$ number of students who have finished studying

$\mathrm{Tt}=$ total number of students

This research is said to be successful, if:

1. The percentage of student learning outcomes increases each cycle and reaches a high predicate or $(>75 \%)$ of the success criteria used (Aqib \& Diniati, 2009).

2. There is an increase in the average value of each cycle.

The research was carried out in 2 cycles where each cycle consisted of 2 meetings (each with the google classroom method, and face to face). The implementation of the research refers to the schedule, as shown in Table 1 . The number of students in shift 1 and shift 2 respectively, is 15 ( 8 males and 7 females) and 14 students (7 males and 7 females). Observational data obtained were analyzed descriptively qualitatively by presenting data in the form of descriptions and discussions based 
on research results. We analyzed the data from the test results quantitatively using descriptive statistics, namely: average score and percentage, besides that, the standard deviation of the frequency table and the percentage of the minimum and maximum values that students obtained at the end of each cycle.

\section{RESULTS AND DISCUSSION}

In the pre-cycle process, an initial test was carried out and data was obtained that from 29 students of class X MIPA3 there was the lowest score of 20 as many as 3 people and the highest score of 80 as many as 5 people with an average score of 52.07 (see Table 3). Judging from the aspect of the percentage of students' complete learning outcomes (see Table 4), where in the pre-cycle students who completed only 5 people $(17.24 \%)$. These data show that the ability of students to understand the material being taught is still far from what is expected. To overcome this, classroom action research (CAR) was carried out to improve the quality of learning practices so that they could achieve the expected standards. Then, 2 cycles were designed consisting of planning, implementation, observation and reflection so that the expected value was achieved.

In the first cycle was obtained an increasing in value when compared to the precycle. The lowest score of 30 was obtained by 2 students and the highest score was 90 obtained by 5 students. From these data, we can see that there was an increase followed by an increase in the class average to 63.79. However, the most dominant male students in the class at this stage had only completed 6 students and 8 women (see Table 5). Several factors caused this such as students who dared to ask only 1 person, who actively recorded only 7 students. Meanwhile, those who focus on learning but do not take notes, as well as those who play games are 4 students each.

In addition, only 1 student who submits assignments on time. There are 8 students who are late in submitting assignments and 6 students who do not submit assignments. The discipline of student attendance in Google Classroom is very good. Of the 14 students who were absent due to illness, 1 student. At the second meeting of this cycle, the compliance of students in collecting assignments on time has increased, namely as many as 6 students. Students who are late and who do not submit assignments in a row are 7 and 1 student.

At the second meeting, the face-to-face shift 2 showed quite good progress compared to shift 1 . Students who had the courage to ask questions, answer questions, actively take notes and pay attention were increasingly dominant, so that only 2 students played around and did not focus. Meanwhile, shift 1, who studied virtually with Google Classroom, showed a pretty wonderful improvement compared to face-to-face at the first meeting.

Table 2. Interval of Students' Learning Mastery Score

\begin{tabular}{cc}
\hline Score Interval & Category \\
\hline Value 75 & Not Complete \\
Value 75 & Complete \\
\hline
\end{tabular}

Table 3. Frequency of Student Learning Outcomes Score

\begin{tabular}{lccc}
\hline Score & Pre Cycle & Cycle I & Cycle II \\
\hline Minimum & 20 & 30 & 55 \\
Maximum & 80 & 90 & 100 \\
mean & 52.07 & 63.79 & 78.28 \\
Standard & 20.068 & 21,283 & 12,697 \\
Deviation & & &
\end{tabular}


This increase is not satisfactory enough. The percentage of students' completeness obtained in the first cycle is $48.28 \%$ while the success indicator of this research is $>75 \%$ (Aqib \& Diniati, 2009). However, this improvement is quite good, which is believed to be due to teacher planning for the preparation of learning media, assignments, has been carried out well. We have also observed this and reflected for further action. However, since the completeness value is still $<75 \%$, it is necessary to carry out further treatment, namely cycle II.

Based on the results of the reflection in cycle 1 , the planning made in the second cycle is to prepare learning media that can be displayed on the PC screen and on the students' android phones. This is so that they have a better level of understanding of the subject while studying with Google Classroom. Next, prepare a complete question bank with solutions ranging from easy, medium and difficult difficulty levels so that students have complex thinking skills. Finally, make the final test questions for the second cycle as 20 multiple-choice questions through the google form application. The score given is 5 points for correct answers and 0 points for incorrect answers.

In the second cycle, the score increased again when compared to the first cycle. The lowest score of 55 was obtained by 3 students and the highest score was 100 obtained by 1 student. From these data, we can see that there was an increase followed by an increase in the class average to 78.28 , so that the data indicates that we have achieved the expected success indicators and the cycle is stopped. In addition, there are 22 students who have completed or $75.86 \%$ of the 29 existing students. This result according to (Aqib \& Diniati, 2009) categorized as high because learning completeness is between $71 \%-85 \%$, so this research cycle does not need to be continued in cycle III. It also means classroom action research that is reflective and collaborative and carried out with the aim of improving the quality of classroom learning practices has been well achieved (Sudjana, 2010).
This increase in results is supported by observational data conducted by researchers, where in all aspects such as attendance, student activities during learning and discipline in doing assignments, it has increased significantly both at meeting 1 (face to face) and meeting 2 virtually (google classroom) compared to in cycle 1 . Student participation virtually shows the same symptoms as cycle 1 , which is better than face-to-face meetings. This corresponds toThe results of Gheytasi et al. in (Darmawan, 2014) shows that students who interact a lot with applications on mobile phones are easier to understand the contents of reading texts.

The recap of the data on the percentage of learning outcomes obtained in this study for each cycle is shown in Table 4 and Table 5. The increase in the average grade value occurred in the pre-cycle until the first cycle was $22.5 \%$. Its average value. In the second cycle, there was still an increase in the class average score of $22.7 \%$ against the average value in the first cycle. This value has also been successful with an increase in the class average value of $50.33 \%$ to the average value before we carried this CAR out.

Meanwhile, based on gender, the level of completeness of female students is much better than that of male students (see Table 5). This may be because female students are more serious about participating in the teaching and learning process. They are more diligent than men. Besides that, their prudence and skills in using technology tend to be better than men. These results are in accordance with the results of the study (Sumianingrum et al., 2017) that there is a difference in the average learning outcomes of male and female students, namely 71.76 compared to 75.8 . This shows that the average learning outcomes of female students are $6 \%$ better than male students. We have not studied the exact cause of these symptoms in this study. But overall, these results have confirmed that blended learning (face-to-face and google classroom) is effective in improving student learning outcomes. In addition, this research is also feasible to be applied by physics teacher in the teaching and learning process during the covid-19 pandemic. 
Table 4. Percentage of Complete Learning Outcomes of Students

\begin{tabular}{lccccccc}
\hline & & \multicolumn{4}{c}{ Number of Students } \\
\cline { 3 - 7 } No & Completeness & \multicolumn{2}{c}{ Pre Cycle } & \multicolumn{2}{c}{ Cycle I } & \multicolumn{2}{c}{ Cycle II } \\
\cline { 3 - 8 } & $\begin{array}{c}\text { Number of } \\
\text { Students }\end{array}$ & $\%$ & $\begin{array}{c}\text { Number of } \\
\text { Students }\end{array}$ & $\%$ & $\begin{array}{c}\text { Number of } \\
\text { Students }\end{array}$ & $\%$ \\
\hline 1. & Complete & 5 & 17.24 & 14 & 48.28 & 22 & 75.86 \\
2. & Not Completed & 24 & 82.76 & 15 & 51.73 & 7 & 24.15 \\
\hline & amount & 29 & 100 & 29 & 100 & 29 & 100 \\
\hline
\end{tabular}

Table 5. Percentage of Students' Learning Outcomes Completeness by Gender

\begin{tabular}{|c|c|c|c|c|c|c|c|}
\hline \multirow{3}{*}{ No } & \multirow{3}{*}{ Completeness } & & & \multicolumn{4}{|c|}{ Number of Students } \\
\hline & & \multicolumn{2}{|c|}{ Pre Cycle } & \multicolumn{2}{|c|}{ Cycle I } & \multicolumn{2}{|c|}{ Cycle II } \\
\hline & & Man & Girl & Man & Girl & Man & irl \\
\hline 1. & Complete & 3 & 2 & 6 & 8 & 9 & 13 \\
\hline 2. & Not Completed & 12 & 12 & 9 & 6 & 6 & 1 \\
\hline \multicolumn{2}{|c|}{$\%$ Completeness } & 10.34 & 6.90 & 20.70 & 27.58 & 31.03 & 44.83 \\
\hline \multicolumn{2}{|c|}{$\%$ Incomplete } & 41.38 & 41.38 & 31.03 & 20.70 & 20.70 & 3.45 \\
\hline
\end{tabular}

\section{CONCLUSION}

Based on the results of research and discussion that have been described in the previous chapter, we can conclude that there is an increase in student learning outcomes by applying the blended learning method with face-to-face learning approaches and google classroom. The average student learning outcomes on momentum and impulse materials in the pre-cycle was 52.07 to 63.79 in the first cycle. The average value of this class increased to 78.28 in the second cycle. Meanwhile, the percentage of students' completeness also increased starting from the pre-cycle, namely $17.24 \%$ to $48.28 \%$ in the first cycle and increased to $75.86 \%$ in the second cycle. I said this research to be complete in cycle II, because the achievement of completeness is high.

\section{REFERENCES}

Aqib, Z., \& Diniati, E. (2009). Penelitian Tindakan Kelas untuk Guru SD, SLB, dan TK. Yrama Widya.

Bonk, C., \& Graham, C. (2012). The handbook of blended learning: Global perspectives, local designs. John Wiley \& Sons.

Darmawan, D. (2014). Pengembangan eLearning Teori dan Desain. PT. Remaja Rosdakarya.
Driscoll, M., \& Carliner, S. (2005). Advanced web-based training strategies: Unlocking instructionally sound online learning. John Wiley \& Sons.

Fitriani, F., Samad, A., \& Khaeruddin, K. (2014). Penerapan Teknik Pemberian Reinforcement (Penguatan) Untuk Meningkatkan Hasil Belajar Fisika Pada Peserta Didik Kelas VIII. A SMP PGRI Bajeng Kabupaten Gowa. Jurnal Pendidikan Fisika, 2(3), 192-202.

Juliani, H. (2020). Analisis Yuridis Kebijakan Keuangan Negara dalam Penanganan Pandemi Covid-19 Melalui Peraturan Pemerintah Pengganti Undang-Undang Nomor 1 Tahun 2020. Administrative Law \& Governance Journal, 3(2), 329348.

Kayatun, S., \& Kresnady, H. (2014). Penggunaan Metode Kerja Kelompok untuk Meningkatkan Hasil Belajar Matematika Sekolah Dasar. Jurnal Pendidikan Dan Pembelajaran Khatulistiwa, 3(4).

Kuspriyanto, B., \& Siagian, S. (2013). Strategi pembelajaran dan kemampuan berpikir kreatif terhadap hasil belajar fisika. Jurnal Teknologi Pendidikan, 6(2), 134258.

https://doi.org/10.24114/jtp.v6i2.4990

Mamluah, S., \& Maulidi, A. (2021). Pembelajaran Jarak Jauh (PJJ) di Masa 
Pandemi COVID-19 di Sekolah Dasar. Jurnal Basicedu, 5(2), 869-877.

Ngalim, P. (2011). Evaluasi hasil belajar. Pustaka Pelajar.

Sam's, R. H. (2010). Model Penelitian Tindakan Kelas. Teras.

Sudjana, N. (2010). Evaluasi proses dan hasil pembelajaran. Bumi Aksara.

Sugiyono. (2011). Metode Penelitian Kuantitatif, Kualitatif, dan $R \& D$. Alfabeta.

Sumianingrum, N. E., Wibawanto, H., \& Haryono, H. (2017). Efektivitas Metode
Discovery Learning Berbantuan ELearning di SMA Negeri 1 Jepara. Innovative Journal of Curriculum and Educational Technology, 6(1), 27-35.

Supardi, S. U., Leonard, L., Suhendri, H., \& Rismurdiyati, R. (2015). Pengaruh media pembelajaran dan minat belajar terhadap hasil belajar fisika. Formatif: Jurnal Ilmiah Pendidikan MIPA, 2(1).

Syah, T. (2004). Peran Disiplin pada Perilaku dan Prestasi Belajar. Grasindo. 